\title{
NEOXALINE, A NEW ALKALOID PRODUCED BY ASPERGILLUS JAPONICUS PRODUCTION, ISOLATION AND PROPERTIES
}

\author{
Atsushi Hirano, Yuzuru Iwai, Rokurou Masuma, \\ Kiyorzumi Tei and Satoshi Ömura* \\ Kitasato University and The Kitasato Institute, Minato-ku, Tokyo 108, Japan
}

(Received for publication June 1, 1979)

\begin{abstract}
A new alkaloid named neoxaline has been isolated from culture broth of Aspergillus japonicus Fg-551 by solvent extraction and silica gel chromatography. The compound does not possess antimicrobial activities, but weakly stimulates the central nervous system. The molecular formula of neoxaline has been determined as $\mathrm{C}_{23} \mathrm{H}_{25} \mathrm{~N}_{5} \mathrm{O}_{4}$ on the basis of elemental analysis and its mass spectrometry.
\end{abstract}

We have previously reported on the isolation of new alkaloids from actinomycetes ${ }^{1 \sim 4)}$. In the course of our continuing search of new alkaloid from microorganisms, a new alkaloid named neoxaline was isolated from a fermentation broth of a strain of Aspergillus japonicus by solvent extraction and silica gel chromatography.

The present paper deals with taxonomy of the producing strain, fermentation, isolation, and physicochemical and biological properties of neoxaline.

\section{Taxonomy of the Producing Organism}

The organism which produces neoxaline was obtained from a soil sample collected in Hiroshima Prefecture, Japan.

CZAPEK's agar, malt agar and potato dextrose agar were prepared for the identification of the fungus. A stock culture of the isolate was inoculated onto these media and incubated at $27^{\circ} \mathrm{C}$ and $37^{\circ} \mathrm{C}$, and the growth was observed for about 10 days.

Cultural characteristics and morphology of the organism are summarized in Tables 1 and 2 . The organism has been identified as Aspergillus japonicus by comparison of the cultural characteristics and morphology with those given by RAPER and FENNEL ${ }^{6)}$ for the type species and with $A$. japonicus SAITO IFO 4060 from Institute for Fermentation, Osaka, Japan. The specific strain has been placed on our file as Aspergillus japonicus $\mathrm{Fg}-551$.

\section{Fermentation}

Aspergillus japonicus $\mathrm{Fg}-551$ was maintained on potato-dextrose agar slants. A spore suspension was prepared by addition of $5 \mathrm{ml}$ of sterilized distilled water to a slant, followed by vigorous agitation of the water over the slant surface with a sterile loop. One milliliter of
Table 1. Morphology of the organism.

\begin{tabular}{l|l}
\hline Conidial head & $\begin{array}{l}\text { radiate or split into few indistinct } \\
\text { columns, 103 131 } \mu \text { in diameter } \\
\text { smooth, colorless, 500 850 } \mu \times\end{array}$ \\
Conidiophores & $11 \sim 12 \mu$ \\
Vesicles & $30 \sim 40 \mu$ in diameter and spherical \\
Sterigmata & $\begin{array}{l}\text { uniseriate, 5.6 } \sim 6.1 \times 2.3 \sim 3.5 \mu \\
\text { globose, echinulate, 3.0 3.7 } \mu \text { in } \\
\text { diameter }\end{array}$ \\
\hline
\end{tabular}

* To whom all correspondence should be addressed. 
Table 2. Cultural characteristics at $27^{\circ} \mathrm{C}^{*}$ after 3 and 7 days growth.

\begin{tabular}{|c|c|c|c|c|}
\hline & & Growth (colony size) & Color $^{5)}$ & Remarks \\
\hline CZAPEK's agars & $\begin{array}{l}3 \text { days } \\
7 \text { days }\end{array}$ & $\begin{array}{l}19.7 \sim 20.9 \mathrm{~mm} \\
\text { floccose } \\
50.9 \sim 60.1 \mathrm{~mm} \\
\text { floccose }\end{array}$ & $\begin{array}{l}\text { Light brown ( } 3 \mathrm{lg}) \\
\text { Oyster white }(\mathrm{gsb}) \\
\text { in reverse } \\
\text { Covert brown }(2 \mathrm{nl}) \\
\text { Putty }\left(1 \frac{1}{2} \mathrm{ec}\right) \\
\text { in reverse }\end{array}$ & No soluble pigment \\
\hline Malt agars & $\begin{array}{l}3 \text { days } \\
7 \text { days }\end{array}$ & $\begin{array}{l}32.0 \sim 34.0 \mathrm{~mm} \\
\text { floccose } \\
40.0 \sim 49.0 \mathrm{~mm} \\
\text { floccose }\end{array}$ & 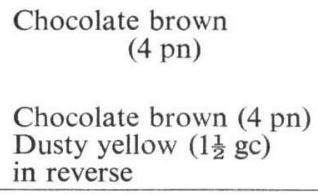 & $\begin{array}{l}\text { More quickly } \\
\text { sporulating than on } \\
\text { CzAPEK's } \\
\text { No soluble pigment }\end{array}$ \\
\hline $\begin{array}{l}\text { Potato dextrose } \\
\text { agar }\end{array}$ & 7 days & $\begin{array}{l}30.5 \sim 37.1 \mathrm{~mm} \\
\text { floccose }\end{array}$ & $\begin{array}{l}\text { Dark brown }(2 \mathrm{pn}) \\
\text { Pastel yellow }(1 \mathrm{fb}) \\
\text { in reverse }\end{array}$ & $\begin{array}{l}\text { More slowly growing } \\
\text { than other two media } \\
\text { No soluble pigment }\end{array}$ \\
\hline
\end{tabular}

* Growth at $37^{\circ} \mathrm{C}$ was poor in these media.

suspension was used for the inoculation of a 1-liter Roux flask containing $400 \mathrm{ml}$ of the following medium: glucose $1.0 \%$, sucrose $2.0 \%, \mathrm{NaNO}_{3} 0.2 \%, \mathrm{~K}_{2} \mathrm{HPO}_{4} 0.1 \%, \mathrm{KCl} 0.05 \%, \mathrm{MgSO}_{4} \cdot 7 \mathrm{H}_{2} \mathrm{O}$ $0.05 \%, \mathrm{FeSO}_{4} \cdot 7 \mathrm{H}_{2} \mathrm{O} 0.001 \%$, corn steep liquor $1.0 \%$ ( $\mathrm{pH}$ adjusted to 6.0 prior to sterilization). The inoculated fermentation medium was incubated at $27^{\circ} \mathrm{C}$ for 7 days to obtain neoxaline. Neoxaline was not produced by submerged culture. The potency of the alkaloid accumulated in culture broth was determined by DRAGENDORFF's method described in our previous article ${ }^{1)}$.

\section{Isolation}

Cultured broth (18 liters) of Aspergillus japonicus Fg-551 obtained by incubation in 50 Roux flasks (1 liter capacity) was used as starting material for isolation of the alkaloid neoxaline. The broth containing mycelia was adjusted to $\mathrm{pH} 10$ with aqueous ammonia. The alkaloid produced was extracted with 8 liters $n$-butyl acetate and then transferred into 3 liters $0.1 \mathrm{~N}$ hydrochloric acid. The water layer was subsequently adjusted to $\mathrm{pH} 10$ with aqueous ammonia and extracted twice with 0.8 liter chloroform. The combined extracts were dried over anhydrous sodium sulfate, concentrated in vacuo to a small volume, and then chromatographed on silica gel ( $60 \mathrm{~g}$, Merck, Kieselgel G) eluting with a solvent mixture of chloroform and methanol (150:1, v/v). Alkaloid fractions, which gave a positive test with DragendorfF's reagent and of which the Rf value was 0.45 on silica gel thin-layer chromatography (chloroform-methanol, 10:1), were collected and evaporated to dryness in vacuo to yield a pale yellowish powder $(350 \mathrm{mg}$ ). The powder was crystallized from benzene to afford colorless needles (230 $\mathrm{mg}$ ) of neoxaline.

\section{Physical and Chemical Properties}

Neoxaline is obtained as basic and lipophilic crystals. Its physical and chemical properties are summarized in Table 3.

The molecular weight and the molecular formula of neoxaline were determined on the basis of its mass spectrum (Found, 435.1863; Calcd. for $\mathrm{C}_{23} \mathrm{H}_{25} \mathrm{~N}_{5} \mathrm{O}_{4}$; 435.1907) and elemental analysis (Table 3). The formula indicated neoxaline to be highly unsaturated. The ultraviolet absorptions showed 
Table 3. Physical and chemical properties of neoxaline.

\begin{tabular}{|c|c|}
\hline Appearance & Colorless needles \\
\hline Melting point & $202^{\circ} \mathrm{C}$ (decomp.) \\
\hline Elemental analysis & $\begin{array}{l}\mathrm{C} 63.23 \% \text {, H } 5.70 \% \text {, N } 15.90 \% \\
\text { no halogen, phosphorus, sulfur }\end{array}$ \\
\hline $\begin{array}{l}\text { Calcd. for } \\
\qquad \mathrm{C}_{23} \mathrm{H}_{25} \mathrm{~N}_{5} \mathrm{O}_{4}\end{array}$ & $\begin{array}{l}\text { C } 63.43 \%, \text { H } 5.79 \% \\
\text { N } 16.08 \%\end{array}$ \\
\hline Molecular weight & $435\left(\mathrm{M}^{+}, m / e\right)$ \\
\hline Molecular formula & $\mathrm{C}_{23} \mathrm{H}_{25} \mathrm{~N}_{5} \mathrm{O}_{4}$ \\
\hline Optical rotation & {$[\alpha]_{\mathrm{D}}^{24}-16.3^{\circ}\left(c 1, \mathrm{CHCl}_{3}\right)$} \\
\hline UV absorption & $\lambda_{\max }^{\mathrm{MeOH}} \mathrm{nm}(\varepsilon), \begin{array}{l}237(17,620), \\
330(29,560)\end{array}$ \\
\hline
\end{tabular}

up at $330 \mathrm{~nm}(\epsilon 29,560)$ and $237 \mathrm{~nm}(\epsilon$ 17,620) in methanol (Fig. 1). The infrared spectrum in $\mathrm{KBr}$ tablet is shown in Fig. 2, which exhibits characteristic bands of amine and/or hydroxyl
Fig. 1. UV spectra of neoxaline.

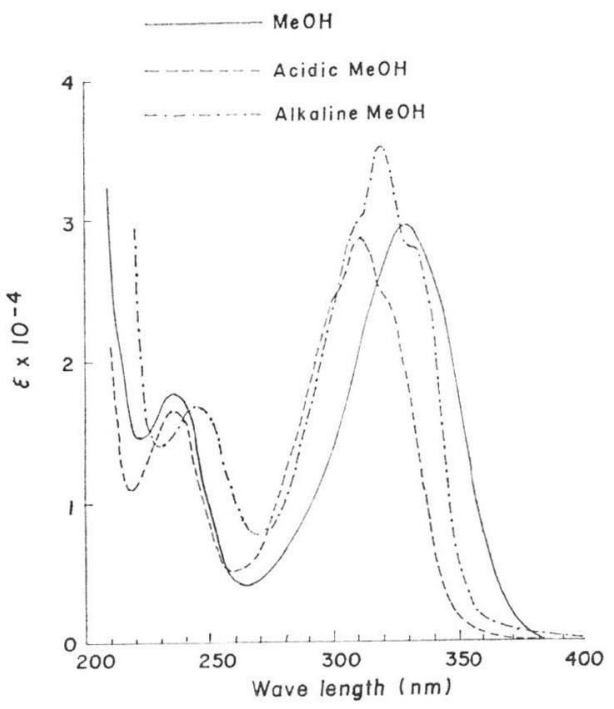
group around $3400 \sim 3100 \mathrm{~cm}^{-1}$, carbonyl and double bond groups at 1700 and $1623 \mathrm{~cm}^{-1}$ respectively, and alkanes around 2960 and $1365 \mathrm{~cm}^{-1}$. The proton NMR spectrum of neoxaline suggested the presence of amine or hydroxyl group at $\delta 12.78$, aromatic and olefinic protons at $\delta 7.6 \sim 6.6$, a methoxyl group at $\delta 3.71$, a methylene group at $\delta 2.35$, and two methyl groups at $\delta 1.27$ (Fig. 3).

Fig. 2. Infrared spectrum of neoxaline (KBr).

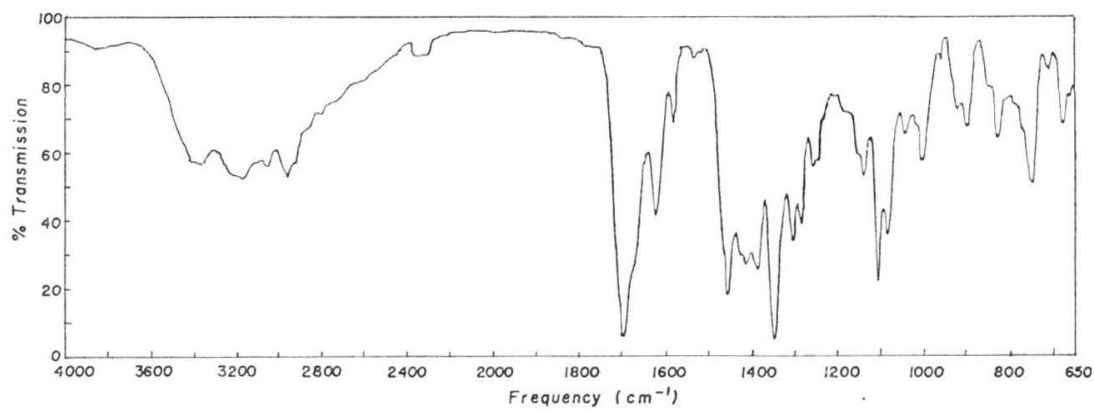

Biological Properties

Neoxaline was found to stimulate weakly the central nervous system by primary test (dose: 100 $\mathrm{mg} / \mathrm{kg}$, mice, p.o.).

The acute toxicity $\left(\mathrm{LD}_{50}\right)$ of the compound by intraperitoneal administration in mice was greater than $200 \mathrm{mg} / \mathrm{kg}$.

Neoxaline was found to have no antibacterial and antifungal activity at levels of $500 \mu \mathrm{g} / \mathrm{ml}$ as shown by the paper disc method. Further investigation on its pharmacological activities is now in progress.

\section{Discussion}

It is known that some alkaloids, such as echinulin ${ }^{7)}$, neoechinulins ${ }^{8,9)}$, fumitremorgin ${ }^{10)}$, ver- 
Fig. 3. NMR spectra of neoxaline $\left(100 \mathrm{MHz}, \mathrm{CDCl}_{3}\right)$.

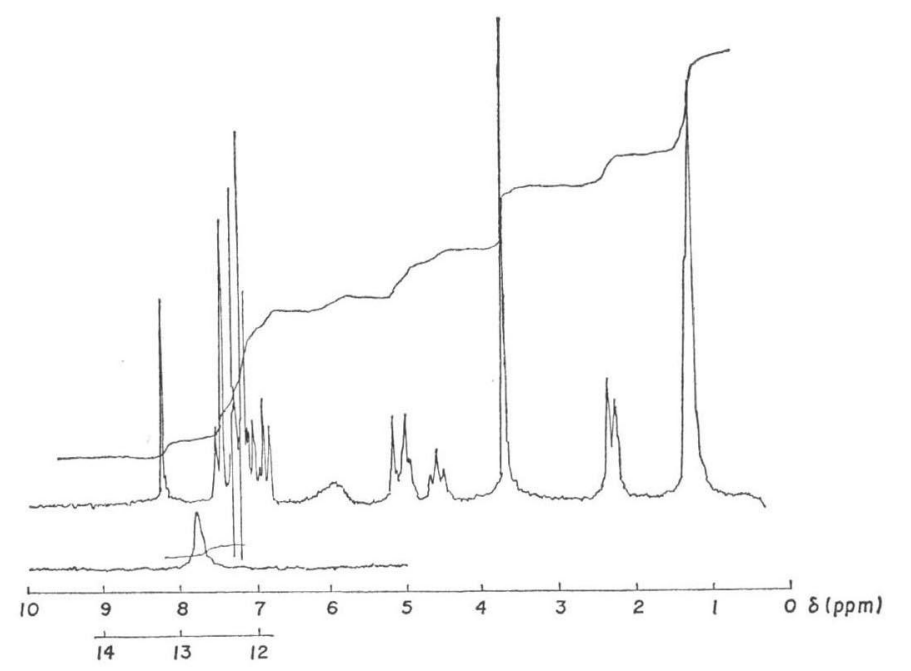

ruculogen $^{11)}$, tryptoguvaline ${ }^{12)}$, nigragilline ${ }^{13)}$ and austamide ${ }^{14)}$ are produced by Aspergillus. Neoxaline was differentiated from those alkaloids by comparison of UV spectra and molecular weight.

Among known alkaloids of microorganism origin, oxaline ${ }^{15)}$ produced by Penicillium oxalicum most closely resembles to neoxaline in physico-chemical properties, especially IR spectrum and NMR spectrum. However, neoxaline is apparently different from oxaline in molecular weight and elemental analysis. Consequently, it can be concluded that neoxaline is a novel alkaloid structurally similar to oxaline.

It is of interest that the compound, structurally closely related to oxaline which is produced by Penicillium, was isolated from Aspergillus. Structure determination is now in progress.

\section{Acknowledgements}

The authors wish to thank Asahi Chemical Industry Co., Ltd. and Toyo Jozo Co., Ltd. for assay of biological activities. Thanks are also due to Dr. Y. KonDA of Kitasato University for valuable suggestions, and Mr. T. YAZAKI and Miss M. KimURA for their technical assistance.

\section{References}

1) Ōmura, S.; H. Tanaka, J. Awaya, Y. Narimatsu, Y. Konda \& T. Hata: Pyrindicin, a new alkaloid from a Streptomyces strain. Taxonomy, fermentation, isolation and biological activity. Agr. Biol. Chem. 38: 899 906, 1974

2) Onda, M.; Y. Konda, Y. Narimatsu, H. Tanaka, J. Awaya \& S. Ōmura: Alkaloids from Streptomyces sp. NA-337. Chem. Pharm. Bull. 22: 2916 2920, 1974

3) ŌMura, S.; Y. SuzuKI, C. KITAO, Y. TAKahashi \& Y. Konda: Isolation of a new sulfur-containing basic substance from a Thermoactinomyces species. J. Antibiotics 28: 609 610, 1975

4) Ōmura, S.; Y. Iwai, A. Hirano, A. Nakagawa, J. Awaya, H. Tsuchiya, Y. Takahashi \& R. Masuma: A new alkaloid AM-2282 of Streptomyces origin. Taxonomy, fermentation, isolation and preliminary characterization. J. Antibiotics 30: 275 282, 1977

5) Container Corporation of America: Color Harmony Manual. 4th edition, Chicago, U.S.A., 1958

6) Raper, K. B. \& D. I. Fennel: The genus Aspergillus. The Williams \& Wilkins Co., Baltimore, 1965

7) Nakashima, R. \& G. P. Slater: The configuration of echinulin. Tetrahedron Lett. 1967: 4433 4436, 1967

8) Dossena, A.; R. Marchelli \& A. Pochini: New metabolites of Aspergillus amstelodami related to the biogenesis of neoechinulin. J. Chem. Soc., Chem. Comm. 1974: 771 772, 1974

9) Cardillo, R.; C. Fuganti, G. Gatti, D. Ghiringhelli \& P. Grasselli: Molecular structure of cryptoechinulin biosynthesis. Tetrahedron Lett. 1974: 3163 3166, 1974 
10) Yamazaki, M.; K. Sasago \& K. MiYaKI: The structure of fumitremorgin B (FTB), a tremorgenic toxin from Aspergillus fumigatus Fres. J. Chem. Soc., Chem. Comm. 1974: 408 409, 1974

11) Fayos, J.; D. Lokensgard, J. Clardy, R. J. Cole \& J. W. Kirksey: Structure of verruculogen, a tremor producing peroxide from Penicillium verruculosum. J. Am. Chem. Soc. 96: 6785 6787, 1974

12) Clardy, J. \& J. P. Springer: Tryptoquivaline and tryptoquivalone, two tremorgenic metabolites of Aspergillus clavatus. J. Am. Chem. Soc. 97: 664 665, 1975

13) CAeser, Von F.; K. JAnsson \& E. Mutshlar: Über Nigragillin, ein neues Alkaloid aus der Aspergillus niger-Gruppe. Pharm. Acta Helv. 44: 676 690, 1973

14) Steyn, P. S.: Austamide, a new toxic metabolite from Aspergillus ustus. Tetrahedron Lett. 1971: $3331 \sim$ 3334, 1971

15) Nagel, D. W.; K. G. R. Pachler, P. S. Steyn, R. Vleggaar \& P. L. Wessels: The chemistry and ${ }^{13}$ C NMR assignments of oxaline, a novel alkaloid from Penicillium oxalicum. Tetrahedron 32: 2625 2631, 1976 